\title{
3,4-Dihydroxyphenylacetic acid (DOPAC) modulates the toxicity induced by nitric oxide in PC-12 cells via mitochondrial dysfunctioning
}

\author{
Carla Nunes, Leonor Almeida, João Laranjinha* \\ Laboratory of Biochemistry, Faculty of Pharmacy, and Center for Neurosciences and Cell Biology University of Coimbra, Couraça dos apóstolos, 51, r/c, 3000 Coimbra, Portugal
}

\section{A R T I C L E I N F O}

\section{Article history:}

Received 9 July 2008

Accepted 9 July 2008

Available online 29 July 2008

\section{Keywords:}

Nitric oxide

DOPAC

Synergism

PC-12 cells

Programmed cell death

Parkinson's disease

Mitochondrial dysfunction

\begin{abstract}
A B S T R A C T
It has been postulated that dihydroxyphenylacetic acid (DOPAC), a major dopamine metabolite, and nitric oxide $\left({ }^{\circ} \mathrm{NO}\right)$ induce mitochondrial dysfunction in a synergistic manner. We examined the combined effects of $\mathrm{NO}$ and DOPAC on PC-12 cells in terms of cell viability, nuclear morphology, mitochondrial parameters and cell death mechanisms. The apoptotic cell death induced by the ${ }^{\circ} \mathrm{NO}-$ donor, $S$-nitroso- $N$-acetylpenicillamine (SNAP), was differently modulated by DOPAC as a function of DOPAC/cell ratios. Whereas below $200 \mathrm{nmol} / 10^{6}$ cells, DOPAC inhibited a typical apoptotic pathway induced by exposure the cells to the ${ }^{\circ} \mathrm{NO}$ donor, above $200 \mathrm{nmol}$ DOPAC $/ 10^{6}$ cells, the cell death was not only enhanced but encompassed a distinct mechanism. Loading the cells with dopamine mimicked the effects of DOPAC. Specifically, the combination of DOPAC and ${ }^{*} \mathrm{NO}$ induced an early mitochondrial membrane potential dissipation and ATP depletion followed by loss of cellular membrane integrity. Mitochondrial dysfunction was accompanied by the release of cytochrome $c$ in both cases, "NO individually and in combination with DOPAC, but caspase- 3 and caspase- 9 activation were only observed in the absence of DOPAC. DOPAC alone was ineffective. Thus, our results suggest a role for DOPAC as a modulator of cell fate and point to a pathway of cell death involving DOPAC and ${ }^{\bullet} \mathrm{NO}$, via mechanisms that include mitochondrial dysfunction but do not involve the activation of the typical apoptotic caspase cascade. The significance of these results is discussed in connection with the mechanisms of cell death underlying Parkinson's disease.
\end{abstract}

(c) 2008 Elsevier Inc. All rights reserved.

\section{Introduction}

Parkinson's disease is one of the most common neurodegenerative diseases that results primarily from the degeneration of dopaminergic neurons in the substantia nigra pars compacta (Bernheimer et al., 1973). Although the precise mechanisms underlying the cell death in Parkinson's disease are not clearly established, several studies suggest that an excessive or inappropriate formation of nitric oxide $\left({ }^{\bullet} \mathrm{NO}\right)$ (and its derivatives) may modulate cell events that are involved in the neuronal death pathways (Przedborski et al., 1996; Schulz et al., 1997; Dawson and Dawson, 1998; Zhang et al., 2006).

The association of ‘NO pathways with Parkinson's disease is strengthened by studies showing that induction of iNOS (inducible

\footnotetext{
* Corresponding author. Tel.: +351 239 852561; fax: +351 239852569.

E-mail address: laranjin@ci.uc.pt (J. Laranjinha).

Abbreviations: ATP, adenosine triphosphate; LDH, lactate dehydrogenase; MTT, 3(4,5-dimethylthiazol-2-yl)-2,5-diphenyl-tetrazolium bromide; $\mathrm{RH} 123$, rhodamine 123; SNAP, $S$-nitroso- $N$-acetylpenicillamine.
}

nitric oxide synthase) in glial cells contributes to degeneration of dopamine-containing neurons in a mice model of Parkinson's disease (Liberatore et al., 1999). Moreover, the inhibition of nNOS (neuronal nitric oxide synthase) prevents Parkinsonism in animal models of the disease (Schulz et al., 1995; Hantraye et al., 1996; Przedborski et al., 1996; Dehmer et al., 2000; Klivenyi et al., 2000; Watanabe et al., 2004, 2008).

On the other hand, the observation that cell death occurred primarily in dopaminergic neurons has focused the attention on the dopamine molecule itself and on an abnormal metabolism of dopamine as a potential mediating factor. In fact, it was reported that dopamine and its metabolites are able to induce toxicity in dopaminergic cells via mechanisms that range from an oxidative stress phenomenon (Fahn and Cohen, 1992; Rabinovic et al., 2000) to specific modifications of critical proteins, such as the covalent modification of parkin (LaVoie et al., 2005), triggering apoptotic death in various neuronal cultures (Jones et al., 2000; Lamensdorf et al., 2000a; Kristal et al., 2001; Lotharius et al., 2005; Mazzio et al., 2004).

Although excessive ${ }^{\bullet} \mathrm{NO}$ production and dopamine or its metabolites have been independently implicated in neurodegeneration, 
several other studies point to links between those two pathways (Antunes et al., 2005). For instance, glutamate potentiates simultaneously $\mathrm{NO}$ production and toxic effects of dopamine towards neuronal cells (Garthwaite and Boulton, 1995). In turn, -NO regulates dopamine release in the hippocampus of rats (Segieth et al., 2000; Wegener et al., 2000), affecting also dopamine reuptake (Cook et al., 1996). Also, 'NO activates tyrosine hydroxylase (the limiting-enzyme in the synthesis of dopamine) (Roskoski and Roskoski, 1987) and mitochondrial damage by ${ }^{\circ} \mathrm{NO}$ is potentiated by dopamine in PC-12 cells (Antunes et al., 2002). Moreover, Laranjinha and Cadenas (2002) reported the formation of reactive intermediates from the interaction of ${ }^{\bullet} \mathrm{NO}$ with 3,4dihydroxyphenylacetic acid (DOPAC), a major metabolite of dopamine. Later, it was demonstrated that DOPAC may act synergistically with ${ }^{\circ} \mathrm{NO}$, leading to mitochondrial dysfunction (Nunes et al., 2005). Therefore, mitochondrial dysfunction and oxidative/nitrosative stress appear to coordinate pathways leading to degeneration of dopaminergic neurons.

The present study entails an assessment of the toxic effects of -NO and DOPAC, independently and in combination, in rat pheochromocytoma-derived PC-12 cells.

Whereas below $200 \mathrm{nmol} / 10^{6}$ cells, DOPAC protects the cells from 'NO-mediated death, when combined with 'NO above $200 \mathrm{nmol}$ DOPAC $/ 10^{6}$ cells, induced an enhanced cell death, involving mitochondrial dysfunction, that is mechanistically distinct from that induced by ${ }^{\bullet} \mathrm{NO}$ as it does not involve caspases activation.

\section{Materials and methods}

\subsection{Chemicals and biochemicals}

DOPAC was purchased from Fluka Chemie (Neu-Ulm, Switzerland). SNAP was obtained from WPI (Sarasota, FL, USA). RPMI 1640 cell culture medium was from Sigma Chemicals Co. (St. Louis, MO, USA); fetal bovine serum (FBS) and phosphate-buffered saline (PBS) pH 7.4 were purchased from Gibco-Invitrogen. General laboratory chemicals as well as poly-lysine, MTT and Hoechst 33258 were from Sigma Chemicals Co. (St. Louis, MO, USA).

DOPAC solution was prepared in ultra pure water (obtained from a Milli-Q system, Millipore Company, Bedford, MA, USA) previously saturated with argon. This solution was prepared every day and used freshly.

To measure the concentration of ${ }^{-N O}$ generated by the ${ }^{*} \mathrm{NO}$ donor $S$-nitroso- $N$-acetylpenicillamine (SNAP) we used the ISO-NO Mark II nitric oxide meter and sensor from WPI (Sarasota, FL, USA).

\subsection{Cell culture}

The rat pheochromocytoma cell line PC-12, purchased from ECACC (European Collection of Cell Cultures), was routinely grown in RPMI 1640 medium without antibiotics supplemented with heat-inactivated fetal bovine serum (FBS) $\left(10 \%\right.$, v/v) onto $75 \mathrm{~cm}^{2}$ flasks and maintained at $37{ }^{\circ} \mathrm{C}$, in a humidified atmosphere of $5 \%$ $\mathrm{CO}_{2}$. Cells were plated $\left(5 \times 10^{4}\right.$ cells cm$\left.{ }^{-2}\right) 24 \mathrm{~h}$ before experiments. The medium was always replaced by fresh medium before treatments of the cells.

\subsection{Analysis of cell viability}

The cell viability was assessed by using the MTT assay, which is based on the reduction of the dye MTT to formazan, an insoluble intracellular blue product, by cellular dehydrogenases (Denizot and Lang, 1986). Briefly, after incubation of the cells under the specified conditions, the culture medium was removed, and the cells washed twice with PBS. Then MTT was added to each well at a final concentration of $0.5 \mathrm{mg} / \mathrm{ml}$. Following incubation during $1 \mathrm{~h}$ at $37^{\circ} \mathrm{C}$, MTT was removed and $1 \mathrm{ml}$ of DMSO was added and mixed thoroughly until formazan crystals were dissolved. The mixture was then collected from each well and the extent of MTT reduction was measured spectrophotometrically at $540 \mathrm{~nm}$. Cell viability was expressed as a percentage of the control cultures.

\subsection{Evaluation of cell death}

The plasma membrane integrity was assessed indirectly by measuring the activity of the cytoplasmic enzyme lactate dehydrogenase (LDH) in the extracellular medium. LDH activity was spectrofluorimetrically evaluated in an auto analyzer Synchron CX (Beckman Coulter) following the manufacturer's instructions. Results were expressed as percentage of total LDH release. Total cellular LDH was determined after lysing the cells.

\subsection{Assessment of cellular morphology}

The cellular morphology was analysed with the May-Grünwald-Giemsa staining. PC-12 cells were plated onto glass coverslips coated with poly-lysine. After incubation under the specified conditions, the cells were washed twice with PBS, fixed with $4 \%$ (w/ v) paraformaldehyde in PBS (15 min), rinsed, and stained with a May-Grünwald solution for $5 \mathrm{~min}$ at room temperature. Then cells were stained with Giemsa solution for $15 \mathrm{~min}$ at room temperature. Cells were rinsed with water. The stained cells were visualized using a Zeiss Axiovert 40 CFL microscope equipped with an Axiocam MRc camera. Only cells that remained attached to the plates were observed.

\subsection{Assessment of nuclear morphology}

The nuclear morphology was analysed with Hoechst 33258, a fluorescent dye that specifically labels nuclear DNA. PC-12 cells were plated onto glass coverslips coated with poly-lysine. After incubation under the specified conditions, the cells were washed twice with PBS, fixed with $4 \%(\mathrm{w} / \mathrm{v})$ paraformaldehyde in PBS $(15 \mathrm{~min})$, rinsed, and stained with Hoechst $33258(5 \mu \mathrm{g} / \mathrm{ml})$ for $10 \mathrm{~min}$ at room temperature. The stained cells were visualized using a Nikon fluorescence microscope employing a DAPI filter. Only cells that remained attached to the plates were observed.

\subsection{Measurement of cytochrome c release}

The release of cytochrome $c$ from mitochondria into the cytosol was assessed by western blot. Briefly, following incubation under the specified conditions, the cells were scraped and centrifuged at $500 \times \mathrm{g}$ for $5 \mathrm{~min}$. Then the cells were washed twice with PBS and resuspended on lysis buffer, consisting of $75 \mathrm{mM} \mathrm{NaCl}, 1 \mathrm{mM}$ $\mathrm{NaH}_{2} \mathrm{PO}_{4}, 8 \mathrm{mM} \mathrm{Na} \mathrm{HPO}_{4}, 250 \mathrm{mM}$ sucrose supplemented with $200 \mu \mathrm{g}$ digitonin/ml and 1:100 of a broad spectrum protease inhibitor cocktail (Sigma Chemical Co.). After vigorous vortexing this suspension was centrifuged at $14000 \mathrm{rpm}$ for $3 \mathrm{~min}$ at $4^{\circ} \mathrm{C}$ and the supernant, corresponding to the cytosolic fraction, recovered. Briefly, $25 \mu \mathrm{g}$ of cytosolic protein extract was loaded onto each lane of a SDS-polyacrylamide gel. The separated proteins were electrotransferred to a polyvinylidene difluoride membrane (Amersham Pharmacia Biotech, Buckinghamshire, UK). The membranes were blocked for $2 \mathrm{~h}$ at room temperature with blocking buffer (15 mM NaCl, $2.5 \mathrm{mM}$ Tris-HCl, pH 7.6, and 0.1\% Tween-20) containing $5 \%$ non-fat dry milk. The blots were then incubated with primary mouse monoclonal antibody against the denatured form of cytochrome $c$ (1:1000, Pharmingen, San Diego, Ca, USA). The membranes were then washed during $30 \mathrm{~min}$ and incubated with 
an alkaline phosphatase-conjugated antibody to mouse immunoglobulin (Ig) (1.15000, Abcam, Cambridge, UK), for $2 \mathrm{~h}$ at room temperature. The bands were revealed with ECF (Amersham Pharmacia Biotech, Buckinghamshire, UK) and visualised by using a Versa-Doc Imaging System, model 3000 (BioRad, Hercules, CA, USA). The images were analysed with the Quantity One software (BioRad). $\beta$-Actin was used as a loading control. Protein concentrations were quantified by the BioRad protein assay dye, using bovine serum albumin as the standard.

\subsection{Measurement of caspase activity}

Following the treatment with DOPAC, SNAP or DOPAC plus SNAP, the cells were harvested and washed twice in PBS. Then, cells were resuspended on a ice lysis buffer consisting of $1 \mathrm{mM} \mathrm{Na}-$ ethylenediaminetetraacetic acid (Na-EDTA), $1 \mathrm{mM}$ Na-ethylene glycol-bis( $\beta$-aminoethylether)- $N, N$-tetraacetic acid (Na-EGTA), $2 \mathrm{mM} \mathrm{MgCl} \cdot 6 \mathrm{H}_{2} \mathrm{O}, 25 \mathrm{mM}$ HEPES ( $\mathrm{pH} 7.5$ ) supplemented with $0.1 \%$ CHAPS, $100 \mu \mathrm{M}$ phenylmethylsulfonyl fluoride (PMSF), $2 \mathrm{mM}$ DTT, and 1:100 of a broad spectrum protease inhibitor cocktail (Sigma Chemical Co.). After freezing during three times in liquid nitrogen, the cell extracts were centrifuged at $15800 \times \mathrm{g}$ for $10 \mathrm{~min}$, at $4{ }^{\circ} \mathrm{C}$ and the supernatants were stored at $-80^{\circ} \mathrm{C}$. To measure caspase activity, aliquots of lysates containing $25 \mu \mathrm{g}$ of protein were added to a reaction buffer (25 mM HEPES, pH 7.5) supplemented with $0.1 \%$ CHAPS, $5 \mathrm{mM}$ DTT and $100 \mu \mathrm{M}$ PMSF. The reactions were initiated after addition of the following fluorimetric substrates (50 $\mu \mathrm{M}$ final concentration): Ac-DEVD-Amc for caspase-3-like activity, Ac-IETD-Amc for caspase-8-like activity and Ac-LEDH-Afc for caspase-9-like activity. After 150 min of incubation at $37{ }^{\circ} \mathrm{C}$ the cleavage of the substrates was measured (Amc, $\lambda$ excitation $390 \mathrm{~nm}$ and $\lambda$ emission $475 \mathrm{~nm}$; Afc, $\lambda$ excitation $400 \mathrm{~nm}$ and $\lambda$ emission $505 \mathrm{~nm}$ ). Caspases activity was expressed as a percentage of the value in control cultures.

\subsection{Determination of ATP levels}

PC-12 cells were seeded onto $40 \mathrm{~mm}$ Petri dish. Following the period of incubation, the medium was removed and the cells were rinsed twice with PBS. Then ice-cold $0.3 \mathrm{M}$ perchloric acid was added and the cells were scraped, collected into Eppendorf tubes, and centrifuged at $15,800 \times \mathrm{g}$, for $5 \mathrm{~min}$ at $4{ }^{\circ} \mathrm{C}$. The pellets were analysed for total protein content using the BioRad protein assay kit. The supernatants were neutralized with $10 \mathrm{M} \mathrm{KOH}$ in $5 \mathrm{M}$ Tris and further centrifuged at $15,800 \times \mathrm{g}$, for $10 \mathrm{~min}$ at $4{ }^{\circ} \mathrm{C}$ to remove the potassium perchlorate salt. The resulting supernatants were assayed for adenosine triphosphate (ATP) using a reverse-phase HPLC methodology, as described by Stocchi et al. (1985) The chromatographic apparatus was a Beckman System Gold, consisting of a 126 binary Pump Model and a 166 Variable UV detector controlled by a computer. The column was a Lichrospher $100 \mathrm{RP}-18$ $(5 \mu \mathrm{M})$ from Merck (Germany). An isocratic elution with $100 \mathrm{mM}$ $\mathrm{KH}_{2} \mathrm{PO}_{4}$ buffer at $\mathrm{pH} 6.5$ with $1 \%$ methanol was performed at flow rate of $0.9 \mathrm{ml} / \mathrm{min}$. The adenine nucleotides were detected at $254 \mathrm{~nm}$.

\subsection{Fluorimetric analysis of mitochondrial membrane potential}

Changes in mitochondrial membrane potential $\left(\Delta \psi_{\mathrm{m}}\right)$ were estimated using the fluorescent cationic dye rhodamine $123(\mathrm{RH}$ 123) as described by Palmeira et al. (1996). RH 123 accumulates electrophoretically in mitochondria as a direct function of the membrane potential and is released upon membrane depolarization. Cells were incubated at $37^{\circ} \mathrm{C}$, for $15 \mathrm{~min}$, with $10 \mu \mathrm{M} \mathrm{RH}$ 123. Then the cells were washed three times with phosphate buffer, centrifuged, resuspended in RPMI 1640 medium without phenol red and transferred to a fluorometer cuvette. The fluorescence at excitation and emission wavelengths of $505 \mathrm{~nm}$ and $525 \mathrm{~nm}$ at $30{ }^{\circ} \mathrm{C}$ was recorded during 3 min using a PerkinElmer LS-50B spectrofluorometer. Then FCCP was added causing release of rhodamine 123 and consequently an increase in fluorescence. Results are expressed as a percentage of the dye retained within control cells.

\subsection{Immunocytochemistry}

Following incubation under the specified conditions, the cells were washed twice with PBS. Then, MitoTracker Deep Red (mitochondria) was added to the culture to a final concentration of $200 \mathrm{nM}$ and incubated for $30 \mathrm{~min}$. Afterwards, the cells were washed twice with PBS and fixed with $4 \%$ paraformaldehyde in PBS for $15 \mathrm{~min}$ at room temperature. After blocking and permeabilization with PBS containing $0.1 \%$ saponin and 5\% FBS for $30 \mathrm{~min}$ at room temperature, cells were incubated with a mouse monoclonal primary antibody anti-apoptotic-inducing factor (AIF) (1:100) (Santa Cruz Biotech, Santa Cruz, USA) for $1 \mathrm{~h}$ at room temperature. Cells were rinsed three times with PBS and then incubated with Alexa fluor 488-conjugated secondary antibody (donkey antimouse IgG, 1:1000) (Molecular Probes, Eugene, OR, USA). The nuclei were stained with Hoechst $33258(5 \mu \mathrm{g} / \mathrm{ml})$ for $10 \mathrm{~min}$ at room temperature. Cells were washed, mounted with Mowiol and observed in a Zeiss Confocal microscope.

\subsection{Statistical analysis}

All data were expressed as mean \pm S.E.M. of at least three independent assays, each one in duplicate. Significance between groups was assessed by one-way analysis of variance (ANOVA). A value of $p$ lower than 0.05 was considered statistically significant.

\section{Results}

\subsection{DOPAC modulation of ${ }^{\bullet} \mathrm{NO}$-induced toxicity on PC-12 cells}

PC-12 cells were treated with two concentrations (0.5 and $1 \mathrm{mM}$ ) of a ${ }^{*} \mathrm{NO}$ donor, SNAP, and assayed for cytotoxicity after 1 , 14 and 24 h incubation (Fig. 1). Typically, ${ }^{\bullet} \mathrm{NO}$ release from $1 \mathrm{mM}$ SNAP, in the presence of cells, reached a steady-state level between 0.8 and $1.3 \mu \mathrm{M}$ after $1 \mathrm{~h}$ in RPMI 1640 medium. Moreover, it was checked that completely decomposed SNAP had no effect on the cell viability (not shown). Fig. 1 shows that SNAP reduced the viability of PC-12 cells in a time- and concentration-dependent manner. Indeed, whereas 0.5 mM SNAP induced a $19.6 \pm 3.3 \%$ and a $28.3 \pm 1.8 \%$ loss of cell viability, at $14 \mathrm{~h}$ and $24 \mathrm{~h}$, respectively, $1 \mathrm{mM}$ SNAP induced a $34.9 \pm 1.1 \%$ and a $52.7 \pm 1.7 \%$ loss of cell viability for identical time ranges (Fig. 1). At $1 \mathrm{~h}$ of incubation, the cell viability was identical to the control.

Fig. 2 shows that the toxicity induced by SNAP is modulated by DOPAC, being the final outcome affected by the concentration of both compounds. When the cells are challenged with $0.5 \mathrm{mM}$ SNAP, DOPAC at $200-400 \mathrm{nmol} / 10^{6}$ cells are protective but $800 \mathrm{nmol} / 10^{6}$ cells is devoided of an effect, being similar to $0.5 \mathrm{mM} \mathrm{SNAP}$ (Fig. 2a). When $1 \mathrm{mM}$ SNAP is used the cells are protected by $200 \mathrm{nmol}$ DOPAC $/ 10^{6}$ cells, but for higher DOPAC/cell ratios an increase in toxicity is obvious (Fig. 2b). Further considering that DOPAC alone, at the concentrations used, had no significant effect on the cell viability for the incubation times shown (data not shown), the results suggest that the cells are sensitive to DOPAC/ ${ }^{\bullet} \mathrm{NO}$ concentration ratio, the lower the concentration of ${ }^{-N O}$, the higher the concentration of DOPAC needed to stimulate toxicity. 


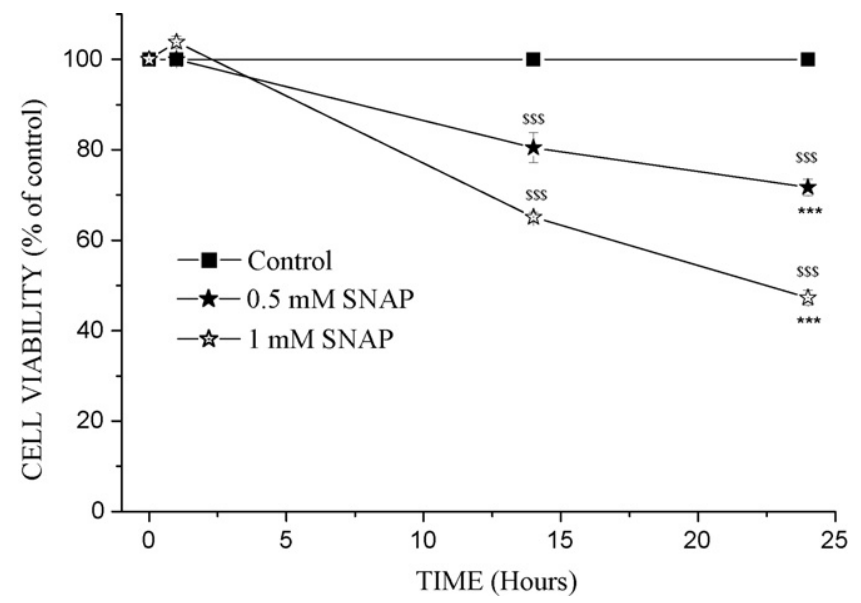

Fig. 1. Evaluation of cell viability of PC-12 cells exposed to SNAP. Cells were plated in 24 well plates containing $0.5 \mathrm{ml}$ covered with poly-D-lysine at the density of $50 \times 10^{3}$ cells $/ \mathrm{cm}^{2}$. After $24 \mathrm{~h}$, the tissue culture media was replaced by fresh media and the cells were incubated with $0.5 \mathrm{mM}$ SNAP or $1 \mathrm{mM}$ SNAP as indicated in the figure. Cell viability was measured at indicated times by determining the cellular reducing capacity, by following the extent of MTT reduction, as described in Section 2. Data represent the mean \pm S.E.M. of at least six independent experiments in triplicate and are expressed as percentage of control cells.
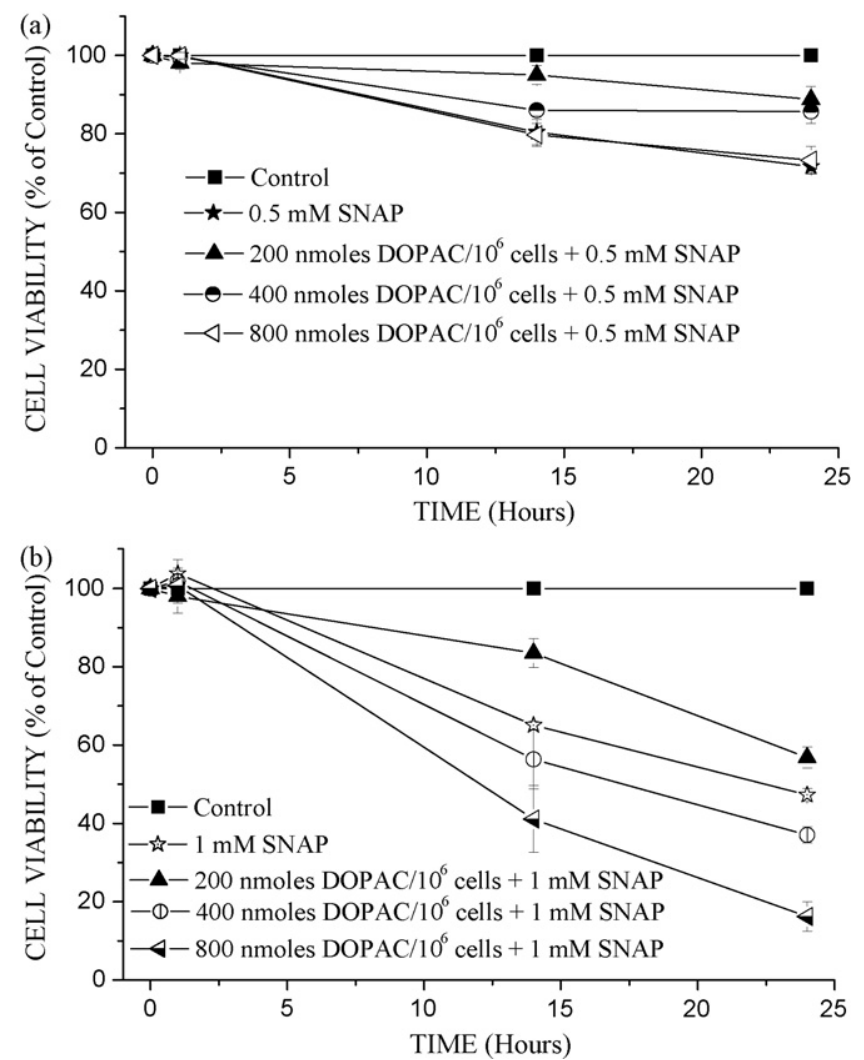

Fig. 2. Effect of DOPAC on SNAP-induced toxicity in PC-12 cells. Experimental conditions were as described in Fig. 1. (a) Cells were incubated during 1,14 and $24 \mathrm{~h}$ with 0.5 mM SNAP, 200 nmol DOPAC $/ 10^{6}$ cells $+0.5 \mathrm{mM}$ SNAP, $400 \mathrm{nmol}$ DOPAC $/ 10^{6}$ cells $+0.5 \mathrm{mM}$ SNAP and $800 \mathrm{nmol}$ DOPAC $/ 10^{6}$ cells + $0.5 \mathrm{mM}$ SNAP, as indicated in figure. (b) The incubation's conditions are as in part (a) except that the concentration of SNAP was $1 \mathrm{mM}$. Data represent the mean \pm S.E.M. of at least six independent experiments in triplicate and are expressed as percentage of control cells.

\subsection{Mechanisms of toxicity}

\subsubsection{LDH leakage}

The integrity of plasma membrane was evaluated as a feature typical of necrosis, by measuring LDH leakage to the extracellular medium induced by $800 \mathrm{nmol}$ DOPAC $/ 10^{6}$ cells, $1 \mathrm{mM}$ SNAP and $800 \mathrm{nmol}$ DOPAC $/ 10^{6}$ cells in combination with $1 \mathrm{mM}$ SNAP after $1 \mathrm{~h}, 4 \mathrm{~h}, 6 \mathrm{~h}, 8 \mathrm{~h}$ and $24 \mathrm{~h}$ of incubation. During the first $8 \mathrm{~h}$ of incubation the membrane integrity of PC-12 cells incubated with SNAP or DOPAC plus SNAP were not significantly affected demonstrating that the cells were still viable (Fig. 3 ). It is of note that membrane integrity is maintained while loss of mitochondrial potential and ATP loss is observed (Figs. 5 and 6 below).

However, as shown in Fig. 3, after $24 \mathrm{~h}$ of incubation with DOPAC plus SNAP, a higher and significant increase of extracellular LDH activity was observed (72.8 \pm 3.4$)$, as compared with the cells incubated with SNAP only $(30 \pm 3.5)$. It is important to note that DOPAC did not induce a significant LDH release into the extracellular medium during $24 \mathrm{~h}$ (Fig. 3).

\subsubsection{Cellular and nuclear morphology}

Hallmarks of classic apoptosis include specific morphological changes, such as cell shrinkage, blebbing, chromatin condensation, nuclear fragmentation and loss of adhesion (Kerr et al., 1972). So, in order to investigate the process of cell death induced by SNAP and DOPAC plus SNAP, the cellular and nuclear morphology of cells treated under the different experimental conditions were analysed by using the May-Grünwald-Giemsa dye and the fluorescent nuclear dye Hoechst 33258, respectively (Fig. 4). Control cells showed a round or spherical morphology with regular and roundshaped nuclei (Fig. 4), whereas treated PC-12 cells manifested a different morphology depending on the experimental conditions. In cultures exposed to $1 \mathrm{mM}$ SNAP, cells were round but some of them showed the nuclei reduced in size and with an irregular shape (Fig. 4). Few blebbing cells are also apparent (Fig. 4). DOPAC plus SNAP-treated cells had a reduced volume when compared

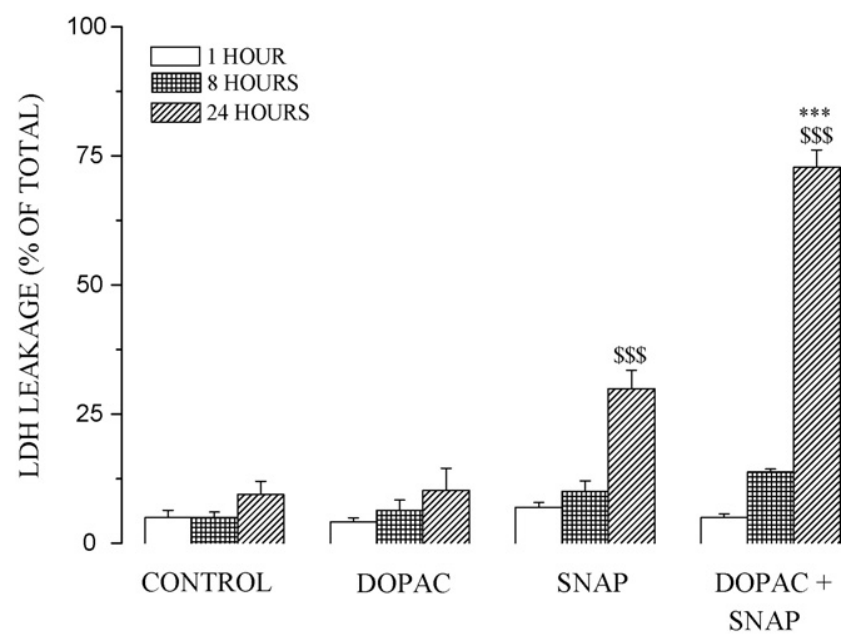

Fig. 3. Effect of co-added DOPAC and SNAP on the cell plasma membrane integrity. The extent of membrane integrity was indirectly assessed by measuring the activity of $\mathrm{LDH}$ in the extracellular medium. Cells were plated in 24 well plates containing $0.5 \mathrm{ml}$ covered with poly-D-lysine at the density of $50 \times 10^{3}$ cells $/ \mathrm{cm}^{2}$. After $24 \mathrm{~h}$, the tissue culture media was replaced by fresh media and the cells were incubated during 1,8 and $24 \mathrm{~h}$ with DOPAC ( $800 \mathrm{nmol} / 10^{6}$ cells), SNAP $(1 \mathrm{mM})$ or DOPAC plus SNAP (nmol DOPAC $/ 10^{6}$ cells $+1 \mathrm{mM}$ SNAP), as indicated in the figure. Then the medium was collected and LDH leakage was expressed as LDH activity in the medium as a percentage of total LDH activity. Data represent the mean \pm S.E.M. of at least four independent experiments. Statistical significance: ${ }^{\$ \$} p<0.001$ as compared to control cells; ${ }^{* * *} p<0.001$ as compared to cells incubated with 1 mM SNAP. 

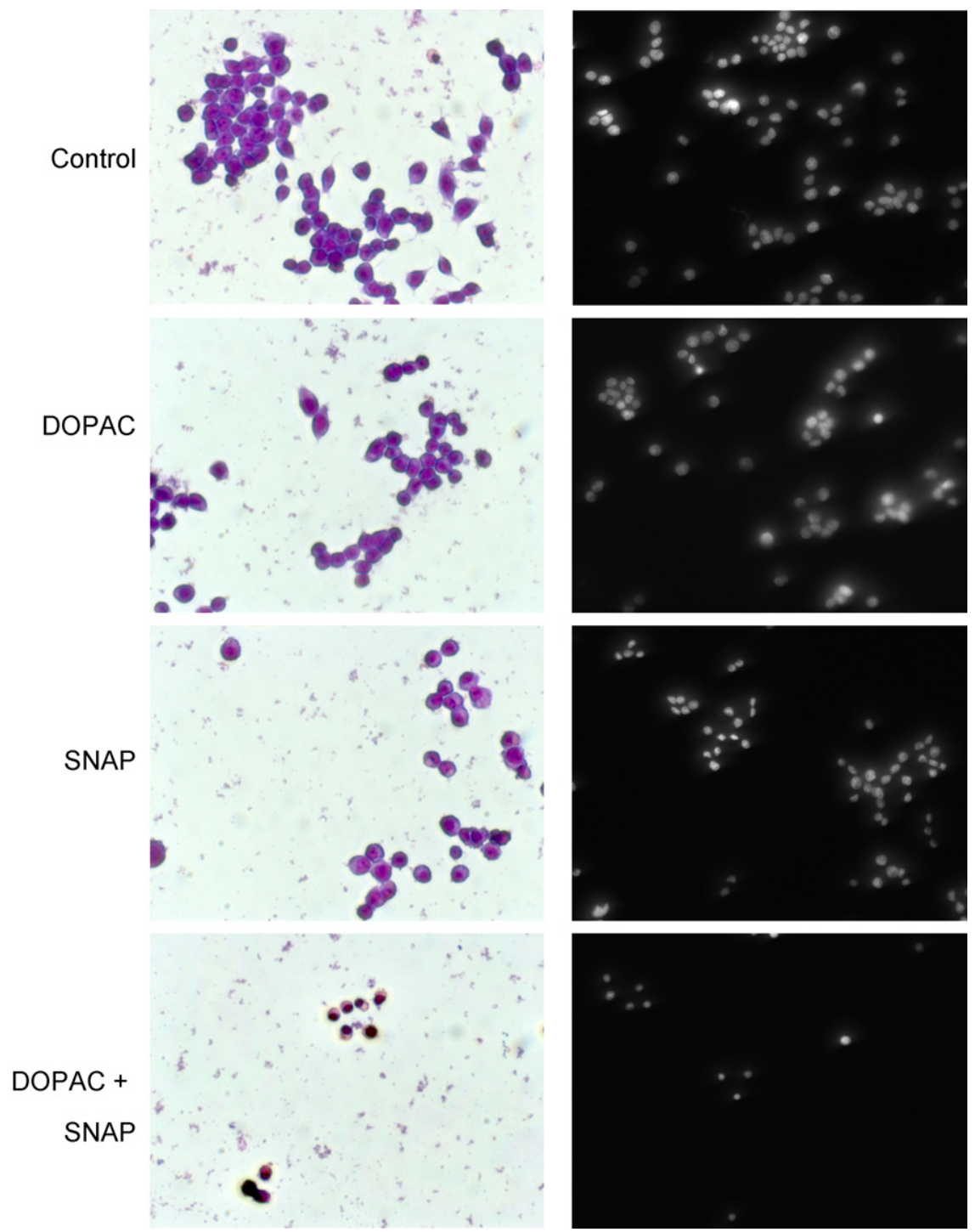

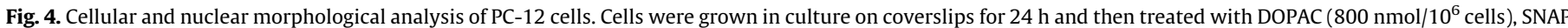

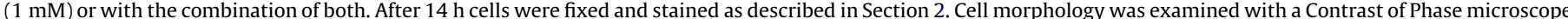
(left panel) and the nuclear morphology was examined with a fluorescence microscope (right panel).

with control cells (cell shrinkage) and the nucleus was strongly condensed (Fig. 4), suggestive of an apoptotic-type mechanism and not a necrotic cell death. Under both conditions, no fragmentation was observed. Note that cells treated with $800 \mathrm{nmol}$ DOPAC $/ 10^{6}$ cells (Fig. 4) did not exhibit noticeable modifications of nuclear morphology relatively to the control cells (Fig. 4).

\subsubsection{Mitochondrial membrane potential and ATP}

Mitochondrial function is very sensitive to the presence of nitric oxide (Brown, 1995; Borutaite and Brown, 1996; Lizasoain et al., 1996; Giulivi, 1998; Brookes et al., 1999; Brown, 1999) and the mechanism by which ${ }^{\bullet} \mathrm{NO}$ induces apoptosis in several cell types appears to encompass changes in mitochondrial membrane potential $\left(\Delta \psi_{\mathrm{m}}\right)$ (Almeida et al., 2001; Bal-Price and Brown, 2000; Brorson et al., 1999; Solenski et al., 2003). To investigate the alteration of $\Delta \psi_{\mathrm{m}}$ in PC-12 cells treated with DOPAC, SNAP or DOPAC plus SNAP, the fluorescent probe RH 123 was used as described in Section 2. As shown in Fig. 5, after $1 \mathrm{~h}$ of incubation, both, SNAP and DOPAC plus SNAP, induced a significant loss of $\Delta \psi_{\mathrm{m}}(72.95 \pm 1.2$ and $60.75 \pm 2.14$, respectively). The dissipation of $\Delta \psi_{\mathrm{m}}$ increased with time under both situations. However, the loss of
$\Delta \psi_{\mathrm{m}}$ was significantly stronger in the cells incubated with DOPAC plus SNAP (Fig. 5). DOPAC had no effect on the $\Delta \psi_{\mathrm{m}}$ (data not shown).

Fig. 6 shows that incubation of cells with $1 \mathrm{mM}$ SNAP or with $800 \mathrm{nmol}$ DOPAC $/ 10^{6}$ cells plus $1 \mathrm{mM}$ SNAP during $1 \mathrm{~h}$ resulted in a similar and significant fall in ATP concentration as compared with the control. However, whereas in the case of cells incubated with $1 \mathrm{mM}$ SNAP, the initial fall in ATP concentration remained unchanged along the incubation time, in the cells co-incubated with DOPAC plus SNAP, ATP concentrations fell progressively over the incubation period. We also evaluated lactate release to the culture medium as an index of glycolytic activity (data not shown). In the cells incubated during $8 \mathrm{~h}$ with SNAP, but not in the cells coincubated with DOPAC plus SNAP, an increase in the lactate production occurred (data not shown). Therefore, these results indicate that DOPAC potentiates the ${ }^{\circ}$ NO-induced ATP depletion in PC-12 cells. In cells incubated with DOPAC alone, we did not observe any significant alteration of the ATP content (Fig. 6).

\subsubsection{Cytochrome c release}

A fall in the $\Delta \psi_{\mathrm{m}}$, may culminate in the release of several proapototic factors from the mitochondrial intermembrane space 


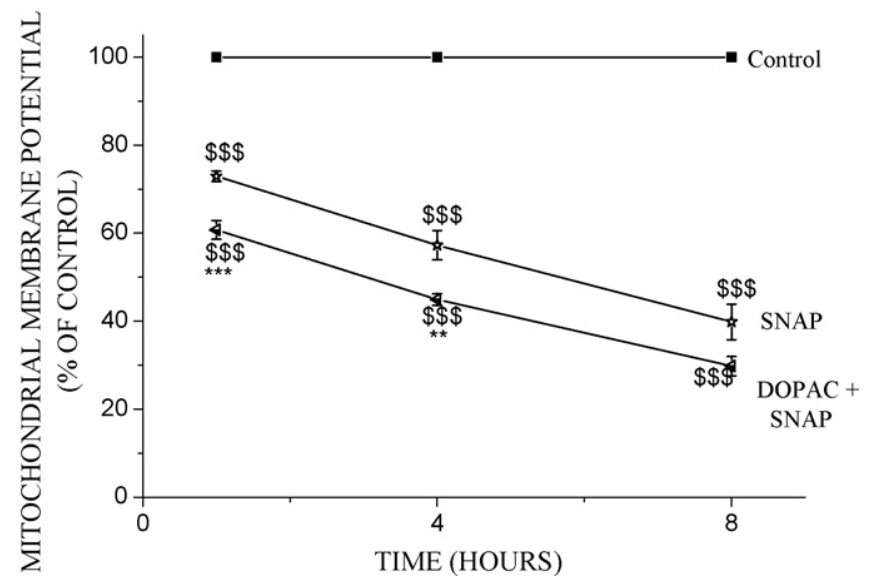

Fig. 5. Effect of SNAP and DOPAC plus SNAP on the mitochondrial membrane potential of PC-12 cells. Cells were plated at a density of $50 \times 10^{3} \mathrm{cells} / \mathrm{cm}^{2}$ in plastic Petri dishes coated with poly-D-lysine. Cells were incubated with DOPAC $\left(800 \mathrm{nmol} / 10^{6}\right.$ cells), SNAP $(1 \mathrm{mM})$ or DOPAC plus SNAP and mitochondrial membrane potential was measured at different time intervals as described in Section 2. Mitochondrial membrane potential was expressed as the percentage of the baseline values of RH 123 cellular retention in control cells, obtained by the difference of fluorescence in the presence and in the absence of FCCP. Data are expressed as the mean \pm S.E.M. derived from five independent experiments. Statistical significance: ${ }^{\$ \$} p<0.001$ as compared to control cells; ${ }^{* * *} p<0.001$ or ${ }^{* *} p<0.01$ as compared to cells incubated with $1 \mathrm{mM}$ SNAP.

to cytosol, notably cytochrome $c$ (Ly et al., 2003). Consequently, we investigated whether cytochrome $c$ release occurred in the cells incubated with SNAP or DOPAC plus SNAP. A western blot analysis of cytosolic fractions derived from PC-12 cells showed that the cytosolic content of cytochrome $c$ increased significantly after $8 \mathrm{~h}$ of incubation with SNAP and DOPAC plus SNAP (Fig. 7), indicating a release of cytochrome $c$ from mitochondria. However, the concentration of cytochrome $c$ in cytosol was higher in cells incubated with DOPAC plus SNAP ( $577 \pm 40 \%$ ) as compared with SNAP alone $(277 \pm 67 \%)$. DOPAC itself did not induce a significant release of cytochrome $c$ when compared with control cells (Fig. 7).

\subsubsection{Caspase activation}

The release of cytochrome $c$ from mitochondria can initiate activation of apoptotic proteases, caspases, leading to cell death. To

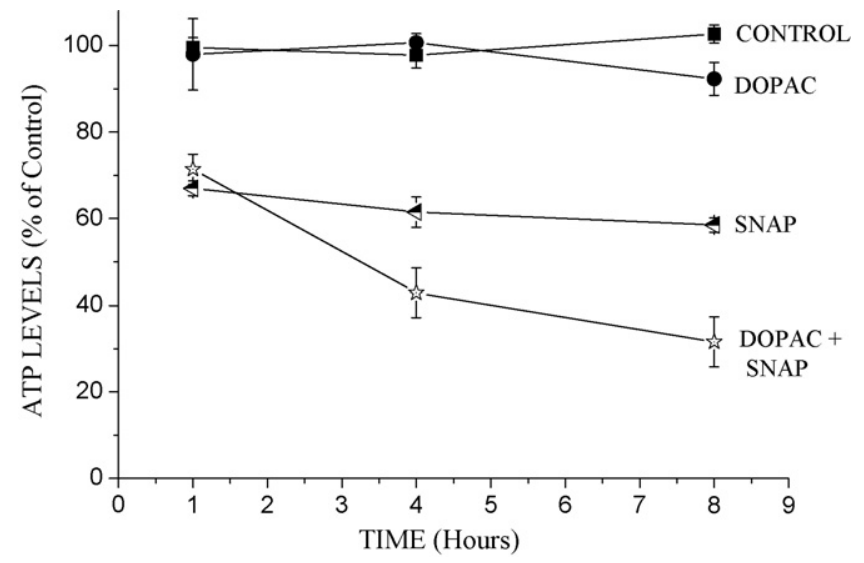

Fig. 6. Adenosine triphosphate (ATP) levels in PC-12 cells after exposure to SNAP or DOPAC plus SNAP. Cells were plated at a density of $50 \times 10^{3} \mathrm{cells} / \mathrm{cm}^{2}$ in plastic Petri dishes coated with poly-D-lysine. Cells were incubated with DOPAC $\left(800 \mathrm{nmol} / 10^{6}\right.$ cells $)$, SNAP $(1 \mathrm{mM})$ or DOPAC plus SNAP. Cellular ATP contents were measured at indicated times by HPLC as described in Section 2. Data represent the mean \pm S.E.M. of eight experiments in duplicate and are expressed as percentage of control cells.
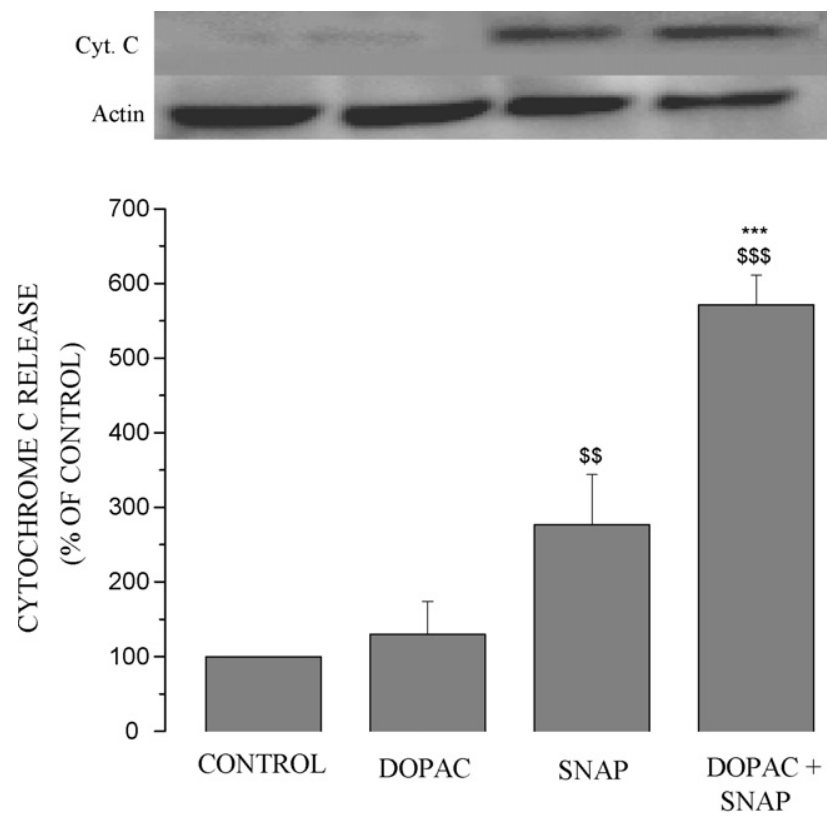

Fig. 7. Immunoblot analysis of cytochrome $c$ in the cytosolic fractions of PC-12 cells. Cells were incubated with DOPAC $\left(800 \mathrm{nmol} / 10^{6}\right.$ cells $)$; SNAP $(1 \mathrm{mM})$ or DOPAC plus SNAP during $8 \mathrm{~h}$. The cytosolic fractions were prepared as described in Section 2. Cytosolic proteins $(25 \mu \mathrm{g})$ were subjected to immunoblot analysis using cytochrome $c$ antibodies and the resulting blots were quantified as described in Section $2 .{ }^{\$ \$} p<0.001$ or ${ }^{\$ \$} p<0.01$ as compared to control cells; ${ }^{* * *} p<0.001$ as compared to cells incubated with $1 \mathrm{mM}$ SNAP.

examine whether the cell death induced by SNAP or DOPAC plus SNAP is related to a pathway involving the activation of caspases, we studied the time course of the activation of caspase-3-, 8- and 9-like proteases. Cytosolic fractions from PC-12 cells were exposed to DOPAC, SNAP or DOPAC plus SNAP for different times (30 min, $2 \mathrm{~h}, 4 \mathrm{~h}, 6 \mathrm{~h}, 8 \mathrm{~h}$, and $14 \mathrm{~h}$ ) and tested for the cleaving activity of three fluorogenic substrates (Ac-DEVD-Amc, Ac-IETD-Amc or AcLEDH-Afc) as described under Section 2. As shown in Fig. 8a, following $14 \mathrm{~h}$ treatment of PC-12 cells with $1 \mathrm{mM}$ SNAP, we detected a 1.5-fold increase of caspase-9-like activity as compared with the control. Conversely, in PC-12 cells incubated with DOPAC plus SNAP this caspase was partially inactivated (Fig. 8a). Similarly, caspase- 3 showed a significant activation in cells treated $14 \mathrm{~h}$ with 1 mM SNAP (1.6-fold the control value) (Fig. 8b) but no activation of caspase-3-like activity was detected up to $14 \mathrm{~h}$ after treatment with DOPAC plus SNAP (Fig. 8b).

Under both conditions of incubation, SNAP or DOPAC plus SNAP, caspase-8-like activity was not significantly altered as compared with the activity of untreated cells (data not shown). In cells incubated with DOPAC, the basal activity of these three caspases was similar to basal activity of control cells (data not shown).

To confirm these results, we assessed, with the MTT assay, the cell viability after $24 \mathrm{~h}$ treatment with SNAP or DOPAC plus SNAP in the presence of the $\mathrm{z}-\mathrm{VAD}-\mathrm{fmk}$, which is widely used as a cellpermeant caspase inhibitor in different experimental models, including PC-12 cells (Fujita et al., 2006). $30 \mu \mathrm{M}$ z-VAD-fmk partially protected the cells incubated with $1 \mathrm{mM}$ SNAP but had no protective effect in the cell viability observed in the cells coincubated with DOPAC plus SNAP (data not shown).

Thus, the results suggest that, conversely to SNAP, DOPAC plus SNAP does not induce a typical caspase-dependent process apoptosis, but some alternative type of programmed cell death that is caspase independent. Therefore, DOPAC, not only potentiated ${ }^{-N O}$-induced cell death, but also modifies the type of programmed cell death induced by ${ }^{\bullet} \mathrm{NO}$. 

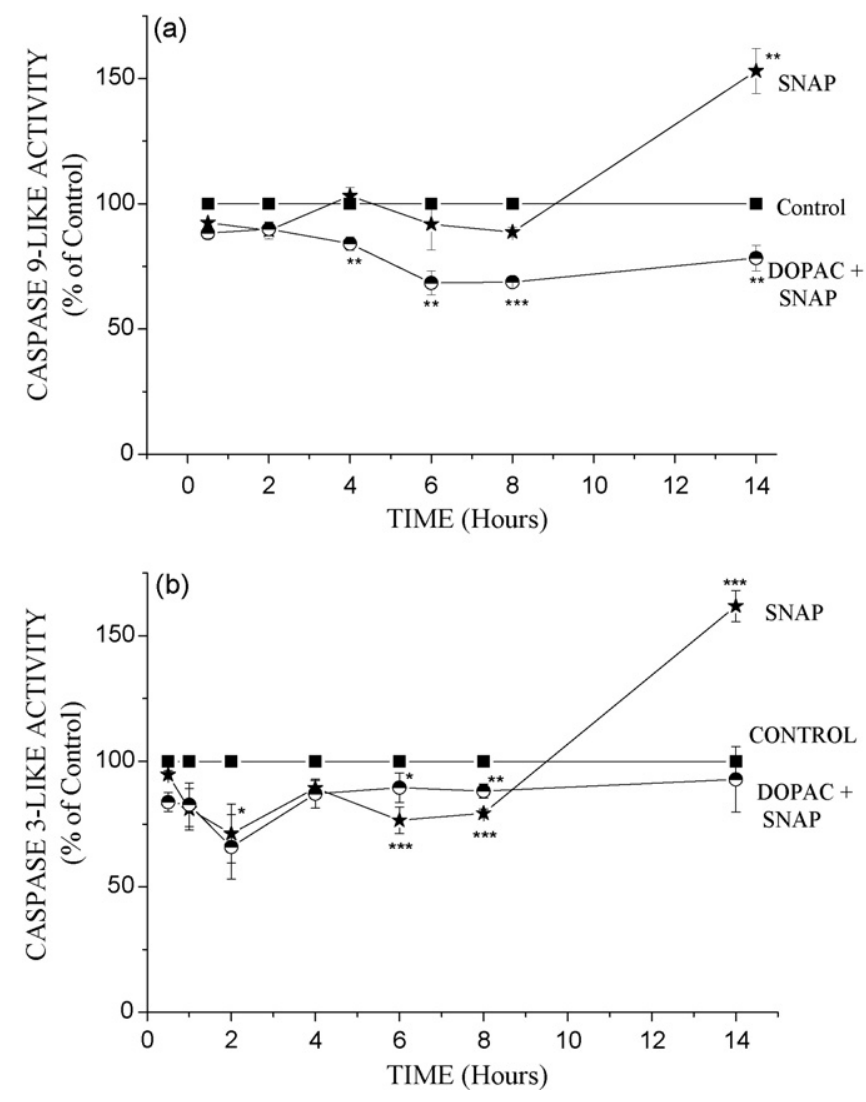

Fig. 8. Fluorimetric evaluation of caspase-9-like (a) and caspase-3-like (b) activities in PC-12 cells exposed to SNAP and to DOPAC plus SNAP. Caspase activity was measured after $0.5,1,2,4,6,8$ or $14 \mathrm{~h}$ incubation with DOPAC $\left(800 \mathrm{nmol} / 10^{6}\right.$ cells $)$, SNAP (1 mM) or DOPAC plus SNAP. Substrate cleaving activity in control cells was taken as $100 \%$. Data represent the mean \pm S.E.M. of 8-12 experiments in duplicate. Statistical significance: ${ }^{* * *} p<0.001$ or ${ }^{* *} p<0.01$ or ${ }^{*} p<0.05$ as compared to control cells.

\subsubsection{AIF nuclear translocation}

Because apoptotic-inducing factor is known to be involved in the induction of apoptotic cell death via a caspase-independent pathway, we next examined whether AIF plays a role in the mechanisms underlying cell death induced by DOPAC plus SNAP (Lorenzo et al., 1999; Susin et al., 1999; Loeffler et al., 2001). Cells were incubated with DOPAC ( $800 \mathrm{nmol} / 10^{6}$ cells), $1 \mathrm{mM}$ SNAP or DOPAC plus SNAP during $8 \mathrm{~h}, 14 \mathrm{~h}$ and $24 \mathrm{~h}$ and then submitted to immunostaining, as indicated in Section 2, with an AIF antibody, concurrently with the mitochondrial marker MitoTracker Deep Red and Hoechst, a nuclear dye. Fig. 9 shows the results obtained after $8 \mathrm{~h}$ of incubation and, apparently, the translocation of AIF to the nucleus did not occur, suggesting that AIF is not mechanistically involved in the cell death induced by DOPAC plus SNAP.

\section{Discussion}

It has been shown that under conditions of excessive or inappropriate formation ' $\mathrm{NO}$ and its derivatives may cause neuronal cell death via mechanisms involving, among others, mitochondrial dysfunction (Dawson and Dawson, 1998; Bolaños et al., 1997; Brown, 1999).

We have previously shown that DOPAC, a major metabolic product of dopamine, inhibits mitochondrial respiration synergistically with ${ }^{N O}$ in isolated brain mitochondria (Nunes et al., 2005). Considering that this event could contribute to the mechanisms of cell death observed during Parkinson's disease, in the present study, we demonstrated that DOPAC modulates the toxic effects of -NO in undifferentiated rat pheochromocytoma-derived PC-12 cells, a cell line widely used as a model for dopaminergic neurons and known to synthesize, store, release and metabolize dopamine in a manner analogous to that of cells in vivo in the mammalian central nervous system (Greene and Tischler, 1976). The undifferentiated PC-12 cells, while preserving dopamine metabolism, are more sensitive to oxidative stress as compared with differentiated cells (Ekshyyan and Aw, 2005).

Once ascertained the concentration of ${ }^{*} \mathrm{NO}$ that caused a significant decrease in cell viability (Fig. 1), we showed that DOPAC affects cell survival in a way dependent on the concentration of both, DOPAC and ${ }^{\bullet} \mathrm{NO}$ (Fig. 2). For $0.5 \mathrm{mM} \mathrm{SNAP} \mathrm{(corresponding} \mathrm{to} \mathrm{a}$ steady-state concentration of about $0.5 \mu \mathrm{M} \bullet \mathrm{NO})$, DOPAC prevented ${ }^{\bullet} \mathrm{NO}$-dependent toxicity when present up to $800 \mathrm{nmol} / 10^{6}$ cells in the medium (Fig. 2a). If the concentration of SNAP doubles (corresponding to a steady-state concentration of about $1 \mu \mathrm{M}$ NO), 400-800 nmol DOPAC $/ 10^{6}$ cells acted synergistically with NO to cause cell death (Fig. $2 \mathrm{~b}$ ).

That ${ }^{\bullet} \mathrm{NO}$, depending on several conditions (e.g., flux of ${ }^{\bullet} \mathrm{NO}$ and time of exposure) and factors (e.g. concentration of oxygen, superoxide radical and thiols), may induce cell death via programmed mechanisms or by necrosis, is extensively documented (Borutaite and Brown, 2005) in several cell types (Bal-Price and Brown, 2000; Terwel et al., 2000; Yuyama et al., 2003). These reports differ not only in the cell type studied but also in the steady-state concentration of the ${ }^{\bullet} \mathrm{NO}$, redox species involved and the chemistry it undergoes in a given biological milieu. Under our experimental conditions, both ${ }^{-N O}$ and the combined action of DOPAC and $\bullet N O$ induced a programmed cell death; only after $24 \mathrm{~h}$ of incubation necrosis is significantly increased (Fig. 3). Moreover, the results indicate that mitochondrial dysfunction is mechanistically involved in the death pathways induced by both, ${ }^{\circledR} \mathrm{NO}$ and DOPAC plus ${ }^{\bullet}$ NO because an early loss ( $1 \mathrm{~h}$ ) of $\Delta \psi_{\mathrm{m}}$ and a depletion of ATP (Figs. 5 and 6, respectively) were observed when signs of cell death were not apparent yet (Figs. 1-3). Preliminary results also indicate that respiratory chain complexes were affected (data not shown). Clearly, Figs. 5 and 6 show that DOPAC had no effect in the $\Delta \psi_{\mathrm{m}}$ and in the ATP levels, but it was able to potentiate the ${ }^{\circ} \mathrm{NO}-$ induced $\Delta \psi_{\mathrm{m}}$ decrease and ATP loss, thus acting synergistically with ${ }^{\bullet} \mathrm{NO}$ in the potential induction of mitochondrial dysfunction. These findings are in agreement with our previous work showing a synergistic inhibition of respiration in isolated rat brain mitochondria by ${ }^{\bullet} \mathrm{NO}$ and DOPAC (Nunes et al., 2005).

In fact, mitochondria is likely the preferential subcellular setting for the interaction of DOPAC with ${ }^{\bullet} \mathrm{NO}$, a statement that may be understood in connection with several lines of evidence, namely: (a) DOPAC synthesis occurs in the mitochondrial matrix via the activity of an unspecific aldehyde dehydrogenase (Ambroziak and Pietruszko, 1991; Keung and Vallee, 1998; Tank et al., 1981); (b) the steady-state level of ${ }^{\bullet} \mathrm{NO}$ in the mitochondrial matrix is expected to be particularly high (Boveris et al., 2000) partially due to the activity of the mitochondrial nitric oxide synthase (mtNOS) (Ghafourifar and Richter, 1997; Giulivi et al., 1998) and also due to the diffusion of NO from other cellular compartments and c) mitochondrial dysfunction seems to have a major role in the pathogenesis of Parkinson's disease (Mizuno et al., 1998; Schapira et al., 1992).

Although, mitochondria is likely to play a center stage in the mechanisms of ${ }^{\bullet} \mathrm{NO}$ and DOPAC plus ${ }^{\bullet} \mathrm{NO}$ toxicities, it appears that DOPAC diverts cell death via a distinct programmed pathway. This notion is supported by the observation that whereas, ${ }^{\bullet}$ NO seems to induce a classical apoptotic programmed cell death with release of cytochrome $c$ from mitochondria (Fig. 7), chromatin condensation (Fig. 4) and activation of caspase-9 (Fig. 8a) and caspase-3 (Fig. 8b), 


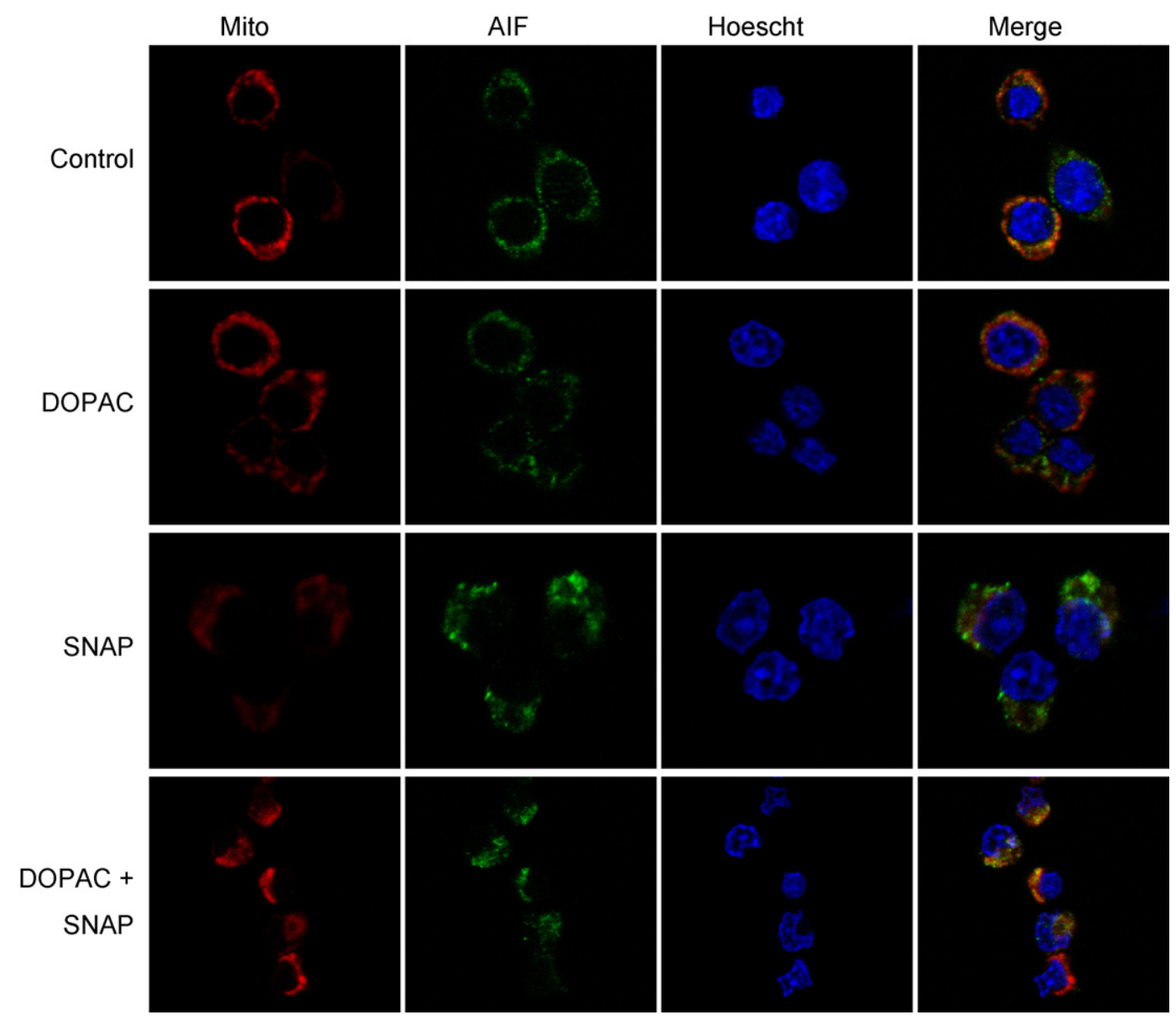

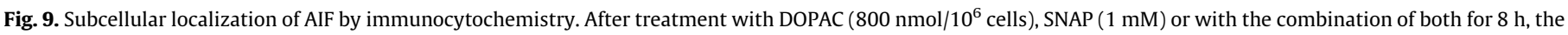

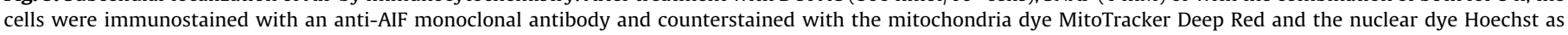
described under Section 2.

when the cells were incubated with DOPAC plus SNAP, cytochrome $c$ release (but in much higher extension than for SNAP alone) (Fig. 7) and condensation of nucleus (Fig. 4) occurred in the absence of caspases activation (Fig. 8a and b). In fact, several studies suggest that in this neurodegenerative disease the neurons can die by a caspase-independent cell death (Graeber et al., 1999; Han et al., 2003; Chu et al., 2005; Liou et al., 2005).

In order to investigate the mechanisms underlying cell death induced by DOPAC plus SNAP, we checked whether the apoptoticinducing factor (AIF), identified as a key player in the caspaseindependent cell death pathway (Lorenzo et al., 1999; Susin et al., 1999; Loeffler et al., 2001) could be involved. AIF is a flavoprotein that in normal conditions is confined to the mitochondrial intermembrane space. In response to apoptogenic stimulus, AIF translocates to the nucleus where it induces chromatin condensation and high molecular weight DNA fragmentation, as well as it evokes dissipation of the $\Delta \psi_{\mathrm{m}}$ and exposure of phosphatidylserine (Susin et al., 2000). However, immunofluorescence experiments suggest that AIF did not translocate to the nucleus (Fig. 9). So, AIF is not the molecule responsible for the cell death that occurs in cells co-incubated with DOPAC and ${ }^{\bullet} \mathrm{NO}$. Lysis of the cells occurred in a late stage of cell death and constitutes probably a secondary necrosis (Fig. 3). Preliminary results - not shown - also indicate that calpains are not involved in the mechanisms of cell death.

Therefore, one may conclude that not only DOPAC potentiates -NO-induced cell death but also modifies the mechanisms of cell death induced by ${ }^{\circ} \mathrm{NO}$. Considering that ${ }^{\bullet} \mathrm{NO}$ and DOPAC may interact yielding free radicals and other reactive species (REF), an oxidative/nitrosative stress is likely to occur.

Given the experimental design used, in which the cells were challenged with a $\mathrm{NO}$ donor and DOPAC, it is important to ascertain that the effects observed are not irrelevant positive results due to an artificial acute damage mediated by oxidation products of DOPAC and $\mathrm{NO}$ chemically produced in the cell incubation medium. First, when cells are loaded with dopamine, in order to increase intracellular DOPAC content, and subsequently exposed to ${ }^{\bullet} \mathrm{NO}$, the effects of DOPAC plus ${ }^{\bullet} \mathrm{NO}$ are mimicked in terms of increased cell death (not shown). Likewise, glipizide $(100 \mu \mathrm{M})$, an inhibitor of DOPAC transport, in the presence of ${ }^{\bullet} \mathrm{NO}$ donor, also potentiated cell death (not shown). These experimental designs were however less reproducible as compared with the situation when cells were directly challenged with DOPAC. Second, even when the cells were incubated during only $1 \mathrm{~h}$ with the DOPAC/SNAP and the medium replaced afterwards, cell death still occurred for later times (not shown). Third, the occurrence of mitochondrial potential loss (Fig. 5) and ATP decline (Fig. 6) under conditions of maintenance of membrane integrity (Fig. 3) imparts biological significance to the experimental model. In connection with this notion, it is also of note to consider that $50-200 \mu \mathrm{M}$ DOPAC are required to achieve a higher DOPAC intracellular steady concentration as PC-12 cells actively secret acidic dopamine metabolites into the surrounding extracellular medium (Lamensdorf et al., 2000b, c). Under our experimental conditions, following 15 min of incubation, a six-fold increase in intracellular DOPAC 
was observed when cells were incubated with ${ }^{\bullet} \mathrm{NO}$ plus $800 \mathrm{nmol}$ DOPAC $/ 10^{6}$ cells (not shown).

In regards to concerns of the physiological significance of high DOPAC concentrations, one might envisage the following situation: since Parkinson's disease is a neurodegenerative disease associated with aging and chronic oxidative stress is involved in the aging process, old dopaminergic neurons could become more susceptible to cell death induced by ${ }^{\circ} \mathrm{NO}$ in presence of lower concentrations of DOPAC.

The synergistic interaction between DOPAC and ${ }^{\circ}$ NO shown here in promoting cell death may also acquire significance for Parkinson's disease under conditions of an increased production of both, ${ }^{-N O}$ and DOPAC, in dopaminergic neurons. In this regard, one may consider the following notions: (i) the concentration of DOPAC found in rat cerebrospinal fluid (CSF) obtained from the third ventricle was c.a. 1.2 $\mu \mathrm{M}$ (Mignot et al., 1984). If one assumes that a concentration gradient is operative from its local of synthesis (the mitochondria) and the extracellular fluid, its concentration in brain mitochondria might be much higher than that in CSF; (ii) an increased turnover of dopamine (synthesis and metabolism) is observed in the early stages of Parkinson's disease (Bernheimer et al., 1973; Hornykiewicz and Kish, 1996; Strange, 1992). Such a compensatory mechanism, increasing the cytoplasmic availability of dopamine, may boost DOPAC concentration due to activated monoamine oxidase activity (Hastings and Zigmond, 1997; Cubells

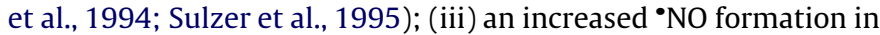
Parkinson's disease has been widely suggested (Gerlach et al., 1999; Hantraye et al., 1996; Itzhak and Ali, 1996; Schulz et al., 1997).

Therefore, the cell death accompanied by mitochondrial dysfunction and caspase-independent pathways potentiated by DOPAC in the presence of $\mathrm{NO}$ may be of significance in the mechanisms of cellular degeneration underlying Parkinson's disease.

\section{Acknowledgements}

Carla Nunes is a recipient of the fellowship SFRH/BD/5428/2001 from FCT, Portugal. This work was supported by FCT Grants POCTI/ 2001/BCI/42365 and PTDC/AGR-ALI/71262/2006. We thank Luísa Cortes for assistance with the confocal microscope imaging studies.

\section{Conflict of interest}

None.

\section{References}

Almeida A, Almeida J, Bolanos JP, Moncada S. Different responses of astrocytes and neurons to nitric oxide: the role of glycolytically generated ATP in astrocyte protection. Proc Natl Acad Sci USA 2001;98:15294-9.

Ambroziak W, Pietruszko R. Human aldehyde dehydrogenase. Activity with aldehyde metabolites of monoamines, diamines, and polyamines. J Biol Chem 1991;266:13011-8.

Antunes F, Han D, Rettori D, Cadenas E. Mitochondrial damage by nitric oxide is potentiated by dopamine in PC12 cells. Biochim Biophys Acta 2002;1556:233-8.

Antunes F, Nunes C, Laranjinha J, Cadenas C. Redox interactions of nitric oxide with dopamine and its derivates. Toxicology 2005;208:207-12.

Bal-Price A, Brown GC. Nitric oxide-induced necrosis and apoptosis in PC12 cells mediated by mitochondria. J Neurochem 2000;75:1455-64.

Bernheimer H, Birkmayer W, Hornykiewicz O, Jellinger K, Seitelberger F. Brain dopamine and the syndromes of Parkinson and Huntington. Clinical, morphological and neurochemical correlations. J Neurol Sci 1973;20:415-55.

Bolaños JP, Almeida A, Stewart V, Peuchen S, Land JM, Clark JB, Heales SJR. Nitric oxidemediated mitochondrial damage in the brain: mechanisms and implications for neurodegenerative diseases. J Neurochem 1997;68:2227-40.

Borutaite V, Brown GC. Rapid reduction of NO by mitochondria, and reversible inhibition of mitochondrial respiration by NO. Biochem J 1996;315:295-9.

Borutaite V, Brown G. What else has to happen for nitric oxide to induce cell death? Biochem Soc Trans 2005:33:1394-6.
Boveris A, Arnaiz SL, Alvarez S, Costa LE, Valdez L. The mitochondrial production of free radicals. In: Yoshikawa T, Toyokuni S, Yamamoto Y, Naito Y, editors. Free radicals in chemistry biology and medicine. OICA International; 2000256-61.

Brookes PS, Bolanos JP, Heales SJR. The assumption that nitric oxide inhibits mitochondrial ATP synthesis is correct. FEBS Lett 1999;446:261-3.

Brorson JR, Schumacker PT, Zhang H. Nitric oxide acutely inhibits neuronal energy production. J Neurosci 1999;19:147-58.

Brown GC. NO regulates mitochondrial respiration and cell functions by inhibiting cytochrome oxidase. FEBS Lett 1995;369:136-9.

Brown GC. Nitric oxide and mitochondrial respiration. Biochim Biophys Acta 1999;1411:351-69.

Chu CT, Zhu JH, Cao G, Signore A, Wang S, Chen J. Apoptosis inducing factor mediates caspase-independent 1-methyl-4-phenylpyridinium toxicity in dopaminergic cells. J Neurochem 2005;94(6):1685-95.

Cook JA, Wink DA, Blount V, Krishna MC, Hanbauer I. Role of antioxidants in the nitric oxide-elicited inhibition of dopamine uptake in cultured mesencephalic neurons. Insights into potential of nitric oxide-mediated neurotoxicity. Neurochem Int 1996;28:609-17.

Cubells JF, Rayport S, Rajendran G, Sulzer D. Methamphetamine neurotoxicity involves vacuolation of endocytic organelles and dopamine-dependent intracellular oxidative stress. J Neurosci 1994;14:2260-71.

Dawson VL, Dawson TM. Nitric oxide in neurodegeneration. Progr Brain Res 1998;118:215-29.

Dehmer T, Lindenau J, Haid S, Dichgans J, Schulz JB. Deficiency of inducible nitric oxide synthase protects against MPTP toxicity in vivo. J Neurochem 2000;74:2213-6.

Denizot F, Lang R. Rapid colorimetric assay for cell growth and survival. Modifications to the tetrazolium dye procedure giving improved sensitivity and reliability. J Immunol Methods 1986;89:271-7.

Ekshyyan O, Aw TY. Decreased susceptibility of differentiated PC-12 cells to oxidative challenge: relationship to cellular redox and expression of apoptotic protease activator factor-1. Cell Death Differ 2005;12:1066-77.

Fahn S, Cohen G. The oxidant stress hypothesis in Parkinson's disease: evidence supporting it. Ann Neurol 1992;32:804-12.

Fujita H, Ogino T, Kobuchi H, Fujiwara T, Yano H, Akiyama J, Utsumi K, Sasaki J. Cellpermeable cAMP analog suppresses 6-hydroxydopamine-induced apoptosis in PC12 cells through the activation of the Akt pathway. Brain Res 2006;1113:10-23.

Garthwaite J, Boulton CL. Nitric oxide signaling in the central nervous system. Annu Rev Physiol 1995;57:683-706.

Gerlach M, Blum-Degen D, Lan J, Riederer P. Nitric oxide in the pathogenesis of Parkinson's disease. Adv Neurol 1999;80:239-45.

Ghafourifar P, Richter C. Nitric oxide synthase activity in mitochondria. FEBS Lett 1997:418:291-6.

Giulivi C. Functional implications of nitric oxide produced by mitochondria in mitochondrial metabolism. Biochem J 1998;332:673-9.

Giulivi C, Poderoso JJ, Boveris A. Production of nitric oxide by mitochondria. J Biol Chem 1998;273:11038-43.

Graeber MB, Grasbon-Frodl E, Abell-Aleff P, Kosel S. Nigral neurons are likely to die of a mechanism other than classical apoptosis in Parkinson's disease. Parkinsonism Relat Disord 1999;5:187-92.

Greene LA, Tischler AS. Establishment of a noradrenergic clonal line of rat adrenal pheochromocytoma cells which respond to nerve growth factor. Proc Natl Acad Sci USA 1976;73:2424-8.

Han BS, Hon HS, Choi WS, Markelnis GJ, Oh TH, Oh YJ. Caspase-dependent andindependent cell death pathways in primary cultures of mesencephalic dopaminergic neurons after neurotoxin treatment. J Neurosci 2003;23(12):5069-78.

Hantraye P, Brouillet E, Ferrante R, Palfi S, Dolan R, Matthews RT, Beal MF. Inhibition of neuronal nitric oxide synthase prevents MPTP-induced parkinsonism in baboons. Nat Med 1996;2:1017-21.

Hastings TG, Zigmond MJ. Loss of dopaminergic neurons in parkinsonism: possible role of reactive dopamine metabolites. J Neural Transm Suppl 1997;49:103-10.

Hornykiewicz O, Kish SJ. Biochemical pathophysiology of Parkinson's disease. Adv Neurol 1996;45:19-34.

Itzhak Y, Ali SF. The neuronal nitric oxide synthase inhibitor, 7-nitroindazole, protects against methamphetamine-induced neurotoxicity in vivo. J Neurochem 1996;67:1770-3.

Jones DC, Gunasekar PG, Borowitz JL, Isom GE. Dopamine-induced apoptosis is mediated by oxidative stress and is enhanced by cyanide in differentiated PC12 cells. J Neurochem 2000;74:2296-304.

Klivenyi P, Andreassen OA, Ferrante RJ, Lancelot E, Reif D, Beal MF. Inhibition of neuronal nitric oxide synthase protects against MPTP toxicity. Neuroreport 2000;11:1265-8.

Kerr JF, Wyllie AH, Currie AR. Apoptosis: a basic biological phenomenon with wideranging implications in tissue kinetics. Br J Cancer 1972;26:239-57.

Keung WM, Vallee BL. Daidzin and its antidipsotropic analogs inhibit serotonin and dopamine metabolism in isolated mitochondria. Proc Natl Acad Sci USA 1998;95:2198-203.

Kristal BS, Conway AD, Brown AM, Jain JC, Ulluci PA, Li SW, Burke WJ. Selective dopaminergic vulnerability: 3,4-dihydroxyphenylacetaldehyde targets mitochondria. Free Radic Biol Med 2001;30(8):924-31.

Lamensdorf I, Eisenhoefer G, Harvey-Whity J, Nechustan A, Kirk K, Kopin IJ. 3,4Dihydroxyphenylacetaldehyde potentiates the toxic effects of metabolic stress in PC12 cells. Brain Res 2000a;868:191-201.

Lamensdorf I, He L, Nechushtan A, Harvey-White J, Eisenhofer G, Milan R, Rojas E, Kopin IJ. Effect of glipizide on dopamine synthesis, release and metabolism in PC12 cells. Eur J Pharmacol 2000b;388:147-54. 
Lamensdorf I, Hrycyna C, He LP, Nechushtan A, Tjurmina O, Harvey-White J, Eisenhofer G, Rojas E, Kopin IJ. Acidic dopamine metabolites are actively extruded from PC12 cells by a novel sulfonylurea-sensitive transporter. Naunyn Schmiedebergs Arch Pharmacol 2000c;361(6):654-64.

Laranjinha J, Cadenas E. Oxidation of DOPAC by nitric oxide. Effect of superoxide dismutase. J Neurochem 2002;81:892-900.

LaVoie MJ, Ostaszewski BL, Weihofen A, Schlossmacher MG, Selkoe DJ. Dopamine covalently modifies and functionally inactivates parkin. Nat Med 2005;11(11): 1214-21.

Liberatore GT, Jackson-Lewis V, Vukosavic S, Mandir AS, Vila M, McAuliffe WG, Dawson VL, Dawson TM, Przedborski S. Inducible nitric oxide synthase stimulates dopaminergic neurodegeneration in the MPTP model of Parkinson disease. Nat Med 1999;5:1403-9.

Liou AK, Zhou Z, Pei W, Lim TM, Yin XM, Chen J. BimEL up-regulation potentiates AIF translocation and cell death in response to MPTP. FASEB J 2005;19(10):1350-2.

Lizasoain I, Moro MA, Knowles RG, Darley-Usmar V, Moncada S. Nitric oxide and peroxynitrite exert distinct effects on mitochondrial respiration which are differentially blocked by glutathione or glucose. Biochem J 1996;314:877-80.

Loeffler M, Daugas E, Susin SA, Zamzami N, Métivier D, Nieminen A, Brothers G, Penninger JM, Kroemer G. Dominat cell death induction by extramitochondrially targeted apoptosis-inducing factor. FASEB J 2001;15:758-67.

Lorenzo HK, Susin SA, Penninger J, Kroemer G. Apoptosis-inducing factor (AIF): a phylogenetically old, caspase-independent effector of cell death. Cell Death Differ 1999;6:516-24.

Lotharius J, Falsig J, van Beek J, Payne S, Drigen R, Brundin P, Leist M. Progressive degeneration of human mesencephalic neuron-derived cells triggered by dopamine-dependent oxidative stress is dependent on the mixed-lineage kinase pathway. J Neurosci 2005;25(27):6329-42.

Ly JD, Grubb DR, Lawen A. The mitochondrial membrane potential $\left(\Delta \psi_{\mathrm{m}}\right)$ in apoptosis; an update. Apoptosis 2003;8(2):115-28 review.

Mazzio EA, Reams RR, Soliman KF. The role of oxidative stress, impaired glycolysis and mitochondrial respiratory redox failure in the cytotoxic effects of 6-hydroxydopamine in vitro. Brain Res 2004;1004(1-2):29-44.

Mignot E, Laude D, Elghozi JL. Kinetics of drug-induced changes in dopamine and serotonin metabolite concentrations in the CSF of the rat. J Neurochem 1984:42: 819-25.

Mizuno Y, Yoshino H, Ikebe S, Hattori N, Kobayashi T, Shimoda-Matsubayashi S, Matsumine H, Kondo T. Mitochondrial dysfunction in Parkinson's disease. Ann Neurol 1998;44(Suppl. 1):S99-109.

Nunes C, Almeida L, Laranjinha J. Synergistic inhibition of respiration in brain mitochondria by nitric oxide and dihydroxyphenylacetic acid (DOPAC). Implications for Parkinson's disease. Neurochem Inter 2005;47:173-82.

Palmeira CM, Moreno AJM, Madeira VMC, Wallace KB. Continuous monitoring of mitochondrial membrane potential in hepatocyte cell suspensions. J Pharmacol Toxicol Methods 1996;35(1):35-43.

Przedborski S, Jackson-Lewis V, Yokoyama R, Shibata T, Dawson VL, Dawson TM. Role of neuronal nitric oxide in 1-methyl-4-phenyl-1,2,3,6-tetrahydropyridine (MPTP)induced dopaminergic neurotoxicity. Proc Natl Acad Sci USA 1996;93:4565-71.

Rabinovic AD, Lewis DA, Hastings TG. Role of oxidative changes in the degeneration of dopamine terminals after injection of neurotoxic levels of dopamine. Neuroscience 2000;101:67-76

Roskoski R Jr, Roskoski LM. Activation of tyrosine hydroxylase in PC12 cells by the cyclic GMP and cyclic AMP second messenger systems. J Neurochem 1987;48: 236-42.
Schapira AHV, Mann VM, Cooper JM, Krige D, Jenner PJ, Marsden CD. Mitochondrial function in Parkinson's disease. Ann Neurol 1992;32:S116-24.

Schulz JB, Matthews RT, Muqit MMK, Browne SE, Beal MF. Inhibition of neuronal nitric oxide synthase by 7-nitroindazole protects against MPTP-induced neurotoxicity in mice. J Neurochem 1995;64:936-9.

Schulz JB, Matthews RT, Klockgether T, Dichgans J, Beal MF. The role of mitochondrial dysfunction and neuronal nitric oxide in animal models of neurodegenerative diseases. Mol Cell Biochem 1997;174:193-7.

Segieth J, Fowler L, Whitton P, Pearce B. Nitric oxide-mediated regulation of dopamine release in the hippocampus in vivo. Neuropharmacology 2000;39:571-7.

Solenski NJ, Kostecki VK, Dovey S, Periasamy A. Nitric oxide-induced depolarization of neuronal mitochondria: implications for neuronal cell death. Mol Cell Neurosci 2003;24:1151-69.

Stocchi V, Cucchiarini L, Chiarantini L, Palma P, Crescentini G. Simultaneous extraction and reverse-phase high performance liquid chromatographic determination of adenine and pyridine nucleotides in human red blood cells. Anal Biochem 1985;146:118-24.

Strange PG. Parkinson's disease. In: Brain biochemistry and brain disorders. Oxford: University Press; 1992.

Sulzer D, Chen TK, Lau YY, Kristensen H, Rayport S, Ewing A. Amphetamine redistributes dopamine from synaptic vesicles to the cytosol and promotes reverse transport. J Neurosci 1995;15:4102-8.

Susin SA, Lorenzo HK, Zamzami N, Marzo I, Snow BE, Brothers GM, Mangion J, Jacotot E, Constantini P, Loeffler M, Larochette N, Goodlett DR, Aebersold R, Siderovski DP, Penninger JM, Kroemer G. Molecular characterization of mitochondrial apoptosisinducing factor. Nature 1999;397(6718):441-6.

Susin SA, Daugas E, Ravagnan L, Samejma K, Zamzami N, Loeffler M, Constantini P, Ferri KF, Irinopoulou T, Prevost MC, Brothers GM, Mak TW, Penninger JM, Earnshaw WC, Kroemer G. Two distinct pathways leading to nuclear apoptosis. J Exp Med 2000;192:571-80.

Tank AW, Weiner H, Thurman JA. Enzymology and subcellular localisation of aldehyde oxidation in rat liver. Oxidation of 3,4-dihydroxyphenylacetaldehyde derived from dopamine to 3,4-dihydroxyphenylacetic acid. Biochem Pharmacol 1981;30:3265-75

Terwel D, Nieland LJM, Schutte B, Reutelingsperger CPM, Ramaekers FCS, Steibusch HWM. S-Nitroso- $N$-acetylpenicillamine and nitroprusside induce apoptosis in a neuronal cell line by the production of different reactive molecules. Eur J Pharmacol 2000;400:19-33.

Watanabe H, Muramatsu Y, Kurosaki R, Michimata M, Matsubara M, Imai Y, Araki T. Protective effects of neuronal nitric oxide synthase inhibitor in mouse brain against MPTP neurotoxicity: an immunohistological study. Eur Neuropsychopharmacol 2004;14(2):93-104.

Watanabe Y, Kato H, Araki T. Protective action of neuronal nitric oxide synthase inhibitor in the MPTP mouse model of Parkinson's disease. Metab Brain Dis 2008;23(1):51-69.

Wegener G, Volke V, Rosenberg R. Endogenous nitric oxide decreases hippocampal levels of serotonin and dopamine in vivo. Br J Pharmacol 2000;130:575-80.

Yuyama K Yamamoto $\mathrm{H}$, Nishizaki I, Kato T, Sora I, Yamamoto T. Caspase-independent cell death by low concentrations of nitric oxide in PC12 cells: involvement of cytochrome c oxidase inhibition and the production of reactive oxygen species in mitochondria. J Neurosci Res 2003;73:351-63.

Zhang L, Dawson VL, Dawson TM. Role of nitric oxide in Parkinson's disease. Pharmacol Ther 2006;109:33-41. 